\title{
The Influence of Integrated Information and Communication Technology Use in Teaching and Learning on Student Competence at University
}

\author{
$1^{\text {st }}$ Aan Hendrayana \\ Department of Mathematics \\ Education \\ Universitas Sultan Ageng \\ Tirtayasa \\ Serang, Indonesia \\ aanhendrayana@untirta.ac.id
}

\author{
$2^{\text {nd }}$ Sholeh Hidayat \\ Faculty of Education \\ Universitas Sultan Ageng \\ Tirtayasa \\ Serang, Indonesia \\ sholeh.hidayat@untirta.ac.id
}

\author{
3rdHeni Pujiastuti \\ Department of Mathematics \\ Education \\ Universitas Sultan Ageng \\ Tirtayasa \\ Serang, Indonesia \\ henipujiastuti@untirta.ac.id
}

\begin{abstract}
Currently, online learning is inevitable. There have been many studies that suggest that there are many advantages of online learning. To serve the online learning, has created a lot of Learning Manajament System (LMS). Even so, there are currently not many who integrate LMS with Public facilities and services at the University. The University of Sultan Ageng Tirtayasa has developed it. The research method used in this research is quasi experiment. The result of the research shows that students' competence and work are better. In addition, interest and motivation of students to learn to be better. To the end, institutions must be serious about applying learning with the help of ICT by providing financial support and supporting policies.
\end{abstract}

Keywords-integrated ICT, teaching, learning, competence

\section{INTRODUCTION}

Information and communication technology (ICT) has become a basic need that can not be separated in everyday life. In the field of education, ICT plays an important role in facilitating and promoting all its potential elements. For lecturers, ICT can be utilized in teaching and learning, developing learning media, sharing information, and so on. As well as for students, ICT can be utilized in searching for learning resources, sharing information, and learning tools. If we avoid the use of ICT, of course our education will be far behind in other countries.

The optimal use of ICT can make education as a producer of superior human resources. Through superior human resources, we can make our country as a superior country, even beyond other countries. Examples of this superior human resources improvement can be seen from other countries like South Korea, Japan, Taiwan, and many more. Therefore, to be superior country, Indonesia really has to work hard in training its people to be able to utilize ICT well.

Higher education is a superior human resource producer, so it becomes an important element that can advance the field of education. Elements within the Higher Education system, such as educators, faculty, and students should be familiarized with the use of ICT.

ICT provide convenience to us in conveying information and completing our work. However, these benefits should be integrated into the local educational context. Higher education must be create an integrated learning environment with ICT so that graduates ready to adapt ICT when they enter the world of work even they can design ICT systems for their workplace. In addition, the ability to utilize ICT can equip graduates to open up employment opportunities that utilize ICT as a service. For example, in the world of economics, graduates can design forms of online marketing innovation. In the agricultural world, graduates can become online agricultural consultants. In the world of education, graduates can open online learning classes and many more.

ICT utilization for educational needs is a mere ability to use, but students must be able to integrate ICT components for their future needs. As a first step, higher education should familiarize the students to utilize ICT facilities in the implementation of learning.

ICT is not being used instantly. The use of ICT should be systematically designed to achieve the goals expected by the field of education. There are many benefits of ICT for educational purposes, but these benefits must be organized for the educational needs. Therefore, the integrated use of ICT is needed to improve student competence. Students need to 
know the source of learning, learning tools, learning instructions, storage of learning resources, sharing of learning resources, and publishing learning resources.

ICT has a characteristic in managing and organizing learning. For that, the source of learning must also adjust to the characteristics of ICT. Learning resources should be packaged in digital form, whether text, animation or video. In ICT-less learning, printed books are one of the main sources of reference. Currently, printed books can be digitally packaged so it's easy to carry out and access them anywhere and anytime.

One of the learning resource is video. Learning resources of this model is easier to be absorbed by the students because it appears visually and can be repeated. Currently, video data is quite easy to pack because the video storage space not only on the hard drive but also can be on the flash disk even can be save in the gadget.

Currently, the app as a learning tool becomes easy to get. There are thousands of applications ready to be used for the benefit of learning aids. The providers of learning aids are provided by many vendors, eg Play Store from google, AppStore, Microsoft Store from Microsoft, and many more. Currently, vendors offer their app products with many offers including direct purchases, monthly hiring, or owning but the app contains ads. Three product offerings of these applications can be utilized by everyone.

Some of the benefits of ICT are able to share useful information in the form of text in the form of blogs and videos. Of the two benefits, the video is more popular among students because they feel like learning from the source directly so as to minimize miss communication. The advantages of ICT are not easily integrated manually for the benefit of learning. There are currently, systems that have created an integrated learning environment. The system is called Learning Management System (LMS).

The use of ICT in learning should not abandon the purpose of learning because it attaches the objectives of the curriculum that have been outlined according to their respective scholarship. Therefore, it is important that there is an assessment of how scientific competence can be achieved with the use of integrated ICT.

ICT facilities require large storage space but easily accessible at an affordable cost. Currently, many storage facilities that have provided it easily, cheap, and even free as long as it can adjust well. Another factor to consider is the internet connection. In Indonesia internet connection has been entered on the $4 \mathrm{G}$ network. There are more than 7 vendors of internet service providers all of whom have provided $4 \mathrm{G}$ technology. Not to mention the vendor with a cable network that offers speeds exceeding $4 \mathrm{G}$ with viber technology. With such networks, video access and other interactive technologies are easy to navigate properly.
Technology requires hardware and software [1]. In Indonesia, the hardware to support the use of ICT is already owned by Indonesian people, especially those who have higher education. The results of a survey of students at one college, almost no students who do not have a smart phone and all have an intenet connection. Therefore, there is no reason for education in Indonesia to not immediately use ICT in an integrated manner to improve the quality of human resources. The skill of ICT usage has been well controlled because the use of smart phone has been entrenched in Indonesian society, especially on students who are studying in higher education.

One of indicator of success from utilizing a new technological approach is to measure how high the user's interest and motivation. By measuring user interest and motivation it will be seen how enthusiastic their acceptance of new technology because motivation is an important variable as a determinant of learning outcomes [2]. Likewise, interest can be a determinant of learning outcomes because interest has a strong association with prior knowledge of learning [3].

\section{RESEARCH METHOD}

The research method used in this research is quasi experiment. There are two group student in this study, integrated ICT learning group (E) and another is conventional group $(\mathrm{K})$ who learn without integrated ICT. Every group including three classes of student. The design of research can be seen below:

$$
\begin{array}{llll}
\mathrm{E} & : \mathrm{Q}_{1} & \mathrm{X} \mathrm{Q} \\
\mathrm{K} & : \mathrm{Q}_{1} & \mathrm{Y} \mathrm{Q} &
\end{array}
$$

Notes:

E: group of experimental students; $\mathrm{K}$ : group of control students; $\mathrm{Q}_{1}$ : pre test; $\mathrm{Q}_{2}$ : post test; $\mathrm{X}$ : Experiment Group; Y: Control Group

The subjects chosen in this study were students on the same study program and course. However, the selection of subjects for the experimental and control classes is different in the academic year due to the degree of class attendance. Control class are student in the 2016/2017 school year and experiment class are student in the 2017/2018 school year. This research was conducted at Mathematics Education Department, Universitas Sultan Ageng Tirtayasa University. The data of this study were collected from 2017 to 2018 .

\section{RESULT AND DISCUSSION}

\section{A. Result}

The results of the research begins with a study of whether the student provides acceptance or rejection of learning innovation. The question posed is about they refuse, wait, or accept the innovation. This result can be seen at the Figure 1. 


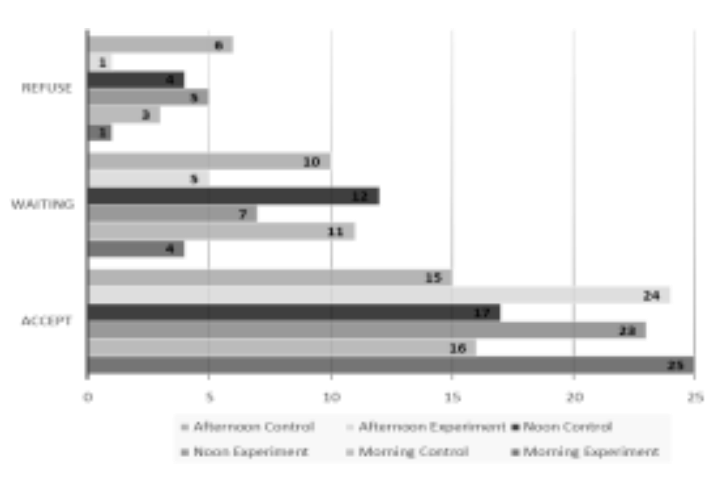

Fig. 1. Rejection and Acceptance of Innovation

The results of the student competence test shown in the Figure 2.

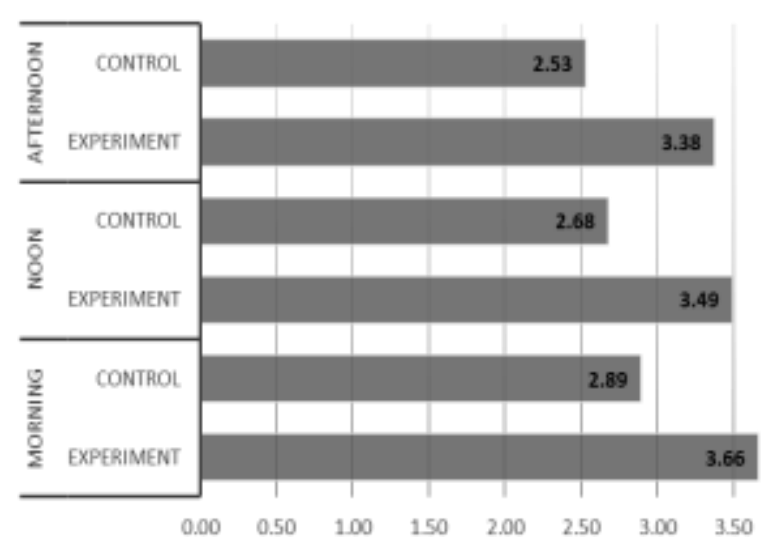

Fig. 2. Student Competence Test Results

Based on the Figure 2 we kown that the competency of the experimental class student is higher than other control group students in every group of student.

\section{B. Interest}

The indicator of this study is how high, interest, and motivation of students in using the integrated ICT system. We use Likert Scale to measure three component above by requesting approval of the conditions applied. Approval consists of four points, namely 1 for very disagree, 2 for disagree, 3 for agree, and 4 for very agree.

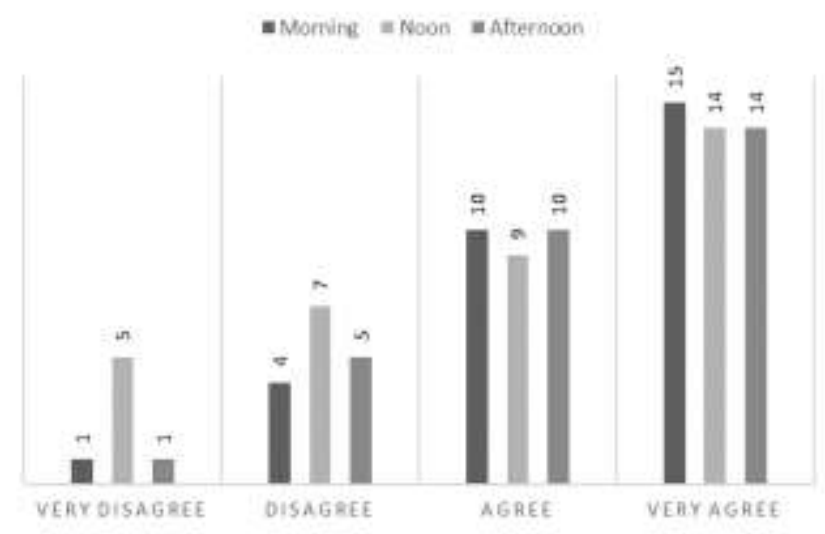

Fig. 3. Students' Interest in ICT Integrated

In general, Figure 3 shows that students interested in learning with the use of integrated ICT but there are few students who are not interested in using ICT in achieving their learning goals.

\section{Motivation}

Looking at the Figure 4, most of students are motivated by a learning approach with the use of integrated ICT. However, there are some students who are not motivated to use integrated ICT in achieving their learning goals.

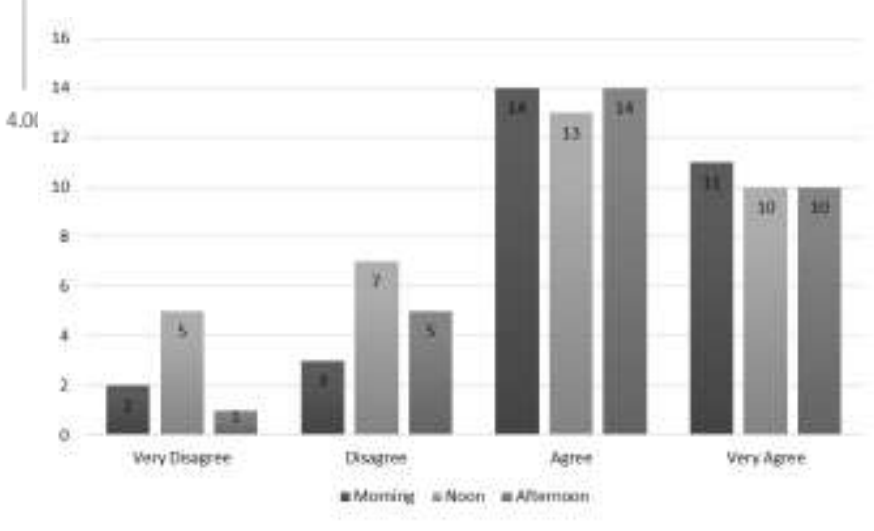

Fig. 4. Student Motivation

There is another interesting data to explore, which is to clarify how much the amount of revenue from interest data and motivation. The results are shown in the figure below: 


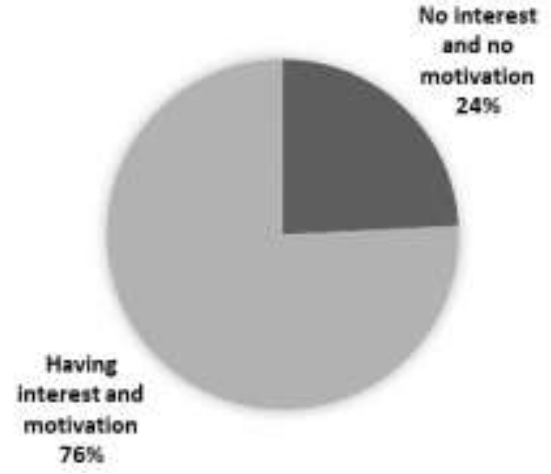

Fig. 5. Acceptance of Interest and Motivation

From Figure 5 it is known that the percentage of student interest and motivation are the same. There are $76 \%$ of students have a good interest and motivation after learning with integrated ICT use and $24 \%$ of students commented otherwise.

\section{Discussion}

Analyzing the acceptance of students towards innovation, the use of integrated ICT has given high expectations to students to achieve learning objectives. Rejection of innovation in grades 1 and 3 is reasonable because of the lack of facilities. Meanwhile, the rejection in group 2 was due to very dense data traffic at 10:00 to $12: 30 \mathrm{pm}$ so that online communication is often disrupted. This rejection is an unfinished part of the study. This research is relevant to [4] research which states that policy holder must take the step of providing internet service well because internet service becomes an important part when ICT-based learning [5-6].

The result of the student's competency test shows that the experimental class student is superior to the other class. These results indicate that learning by using integrated ICT can improve student competence well. It is clear that the advantages of integrated ICT can significantly improve students' ability as the initial assumption. This increase occurs because integrated ICT can encourage students' interest and motivation. In addition, studies of interest and motivation outcomes and their relevance to student competencies need to be examined more as the next research suggestion.

A high interest in learning by using integrated ICT shows that students actually have sufficient prerequisite skills so that the application of learning by using integrated ICT to attract them. The interest held is relevant to the student's early schemes [3,7] and the scheme becomes a provision for understanding the concepts that will be taught and will conclude on subsequent concepts of understanding [8-9]. Learning with respect to the scheme can improve the ability to learn well [10]

Interest and motivation of students on learning by using integrated ICT is $76 \%$. This shows that students' interest and motivation toward learning by using integrated ICT is high enough, while others are $24 \%$.
For that, it is still necessary other efforts of educators and policyholders so that the percentage of $24 \%$ to be smaller.

\section{CONCLUSIONS}

Learning by using integrated ICT can improve student competence. In addition, student interest and motivation are also increasing. Policy holders should pay attention to facilities that support the application of integrated ICT in learning, so that the process is not constrained. To explore the results of the next research is the need for research difficulties how the use of integrated ICT in areas with weak internet network and students with low ICT related initial capabilities.

\section{ACKNOWLEDGMENT}

This study and article would not have been possible without the co-operation of the pathner and pupils in the collage in which I conducted the research. Thanks also to The Ministries of Research, Technology, and Higher Education Republic of Indonesia for their financial support for the project. Finally, I wish to thank my colleagues at the University of Sultan Ageng Tirtayasa and elsewhere, friends, and family for their on-going support.

\section{REFERENCES}

[1] E. M. Rogers and M. Everett. Diffusion of Innovations, 3rd ed., New York: The Free Press, 1983, pp. 138-139.

[2] N. M. Seel, "Empirical Perspectives on Memory and Motivation" in Handbook of Research on Educational Communications and Technology. New York: Lawrence Erlbaum Associates. 2008.

[3] S. Tobias. "Interest, prior knowledge, and learning". Rev. Educ. Res., vol. 64, pp. 37 - 54, 1994.

[4] S. Hidayat, A. Hendrayana and H. Pujiastuti. "Identification of Readiness of Developing University to Apply Information and Communication Technology (ICT) in Teaching and Learning". SHS Web of Conferences 42, 00117. https://doi.org/10.1051/shsconf/20184200117.2018

[5] A. Hendrayana and Wahyudin. "Mobile learning to improve mathematics teachers mathematical competencies". IOP Conf. Series: Journal of Physics: Conf. Series 948, 2018, 012049 doi:10.1088/1742-6596/948/1/012049

[6] A. Hasani and A. Hendrayana. "Use of Social Media for Final Writing Guidance in Higher Education". Adv. Sci. Let, 26782681. 2018

[7] Syamsuri, Purwanto, Subanji, and S. Irawati. "Characterization of students formal-proof construction in mathematics learning". Commun. Sci. Technol. vol. 1, n. 2, pp. 42-50, 2016.

[8] A. Hendrayana. "Pengaruh pembelajaran pendekatan rigorous mathematical thinking (RMT) terhadap pemahaman konseptual matematis siswa SMP". Jur. Ris. Pend. Mat., vol. 4, n. 2, pp. 186-199., 2017. doi:http://dx.doi.org/10.21831/jrpm.v4i2.15385

[9] A. Mutaqin, I. Marethi and Syamsuri. "Model blended learning di Program Studi Pendidikan Matematika Untirta". Cak. Pend., vol. 1, n. XXXV, 2016..

[10] A. Hendrayana. Mengatasi Cognitive-load Pada Anak. Serang: FKIP Publising. 2017. pp.2-8. 